\title{
SEISMIC RESPONSE OF RC FRAME STRUCTURE WITH SOFT STOREY
}

\author{
S.Zubair Ahmed ${ }^{1}$, K.V.Ramana ${ }^{2}$, Ramancharla Pradeep Kumar ${ }^{3}$ \\ ${ }^{I}$ M.Tech Student, Civil Department, G.Pulla Reddy Engineering College, Andhra Pradesh, India \\ ${ }^{2}$ Asst Prof., Civil Department, G.Pulla Reddy Engineering College, Andhra Pradesh, India \\ ${ }^{3}$ Head of the Centre, Earthquake Engineering Research Centre, IIIT Hyderabad, Telangana, India
}

\begin{abstract}
Multistoried buildings with open ground floor are inherently vulnerable to collapse due to earthquake load, their construction is still widespread in the developing nations due to social and functional need for provide car parking space at ground level. Engineering community warned against such buildings from time to time. Along with gravity load structure has to withstand to lateral load which can develop high stresses which leads to destruction of buildings. In this case study R.C.C. building is modeled and analyzed in three cases. I) Model with no infill wall (Bare Model). II) Model with bottom storey open. III) Model with steel bracing system at bottom storey.
\end{abstract}

Dynamic analysis of the building models is performed in ETABS. The performance of the building is evaluated in terms of Storey Drifts, Lateral Displacements, Lateral Forces, Storey Stiffness, Base shear, Time period, Torsion. It is found that steel braced system significantly contributes to the structural stiffness and reduces the maximum inter story drift, lateral displacement of R.C.C building. The results of bare frame, steel braced system and open bottom storey frame are discussed and conclusions are made.

Keywords: Storey Drifts, Storey Stiffness, bare frame.

\section{INTRODUCTION}

The primary purpose of all kinds of structural systems used in the building type of structures is to transfer gravity loads effectively. The most common loads resulting from the effect of gravity are dead load, live load and snow load. Besides these vertical loads, buildings are also subjected to lateral loads caused by wind, blasting or earthquake. Lateral loads can develop high stresses, produce sway movement or cause vibration. Therefore, it is very important for the structure to have sufficient strength against vertical loads together with adequate stiffness to resist lateral forces.

Retrofitting of RC buildings is much more systematic and rational process than that of non-engineered load bearing wall buildings. "Making changes to the systems inside the building or even the structure itself at some point after its initial construction and occupation

\section{AIMS AND OBJECTIVES}

In this study R.C.C. building is modeled and analyzed in five Parts

1. Model with no infill

2. Model with bottom storey open

3. Model with steel bracing system

The performance of the building is evaluated in terms of Storey Drifts, Lateral Displacements, Lateral Forces, Storey Stiffness, Base shear, Time period, Torsion.

\section{METHOD OF ANALYSIS}

The most commonly used methods of analysis are based on the approximation that the effects of yielding can be accounted for by linear analysis of the building, using the design spectrum for inelastic system. Forces and displacements due to each horizontal component of ground motion are separately determined by analysis of an idealized building having one lateral degree of freedom per floor in the direction of the ground motion component being considered. Such analysis may be carried out by the seismic coefficient method (static method) or response spectrum analysis procedure (dynamic method).

\subsection{Response Spectrum Analysis}

In the response spectrum method, the response of a structure during an earthquake is obtained directly from the earthquake response (or design) spectrum. This procedure gives an approximate peak response, but this is quite accurate for structural design applications. In this approach, the multiple modes of response of a building to an earthquake are taken into account. For each mode, a response is read from the design spectrum, based on the modal frequency and the modal mass. The responses of different modes are combined to provide an estimate of total response of the structure using modal combination methods such as complete quadratic combination (CQC), square root of sum of squares (SRSS), or absolute sum (ABS) method. Response spectrum method of analysis should be performed using the design spectrum specified or by a site - specific design spectrum, which is specifically prepared for a 
structure at a particular project site. The same may be used for the design at the discretion of the project authorities

\section{ANALYSIS OF BUILDING FOR DIFFERENT CONFIGURATIONS}

A hypothetical building is assumed for seismic analysis that consists of a G+5 R.C.C. residential building. The plan of the building is irregular in nature as it has all columns not at equal spacing. The building is located in Seismic Zone V and is founded on medium type soil. The building is 24.00 $\mathrm{m}$ in height $28.50 \mathrm{~m}$ in length and $8.17 \mathrm{~m}$ in width. The important

Table -1: Building Features

\begin{tabular}{|c|c|}
\hline Structure & OMRF \\
\hline Floors & G.F +5 \\
\hline Ground storey height & $4.0 \mathrm{~m}$ \\
\hline Typical storey height & $4.0 \mathrm{~m}$ \\
\hline Depth of Foundation & $3.0 \mathrm{~m}$ \\
\hline Live load & $\begin{array}{c}2.0 \mathrm{kN} / \mathrm{m}^{2} \text { [typical floor] } \\
3.0 \mathrm{kN} / \mathrm{m}^{2}[\text { corridors, staircase] } \\
1.5 \mathrm{kN} / \mathrm{m}^{2} \text { [terrace] }\end{array}$ \\
\hline Floor finish & $1.0 \mathrm{kN} / \mathrm{m}^{2}$ \\
\hline Water proofing & $1.0 \mathrm{kN} / \mathrm{m}^{2}$ \\
\hline Storey height & $4 \mathrm{~m}$ \\
\hline Walls Thickness & $230 \mathrm{~mm}$ \\
\hline Materials & $\mathrm{Fe} 415 \& \mathrm{M} 20$ \\
\hline Zone & $\mathrm{V}$ \\
\hline Size of columns & $230 \mathrm{~mm} \times 525 \mathrm{~mm}$ \\
\hline $\begin{array}{c}\text { Sizes of beams in } \\
\text { transverse and } \\
\text { longitudinal direction }\end{array}$ & $230 \mathrm{~mm} \times 450 \mathrm{~mm}$ \\
\hline Thickness of slab & $125 \mathrm{~mm}$ \\
\hline
\end{tabular}

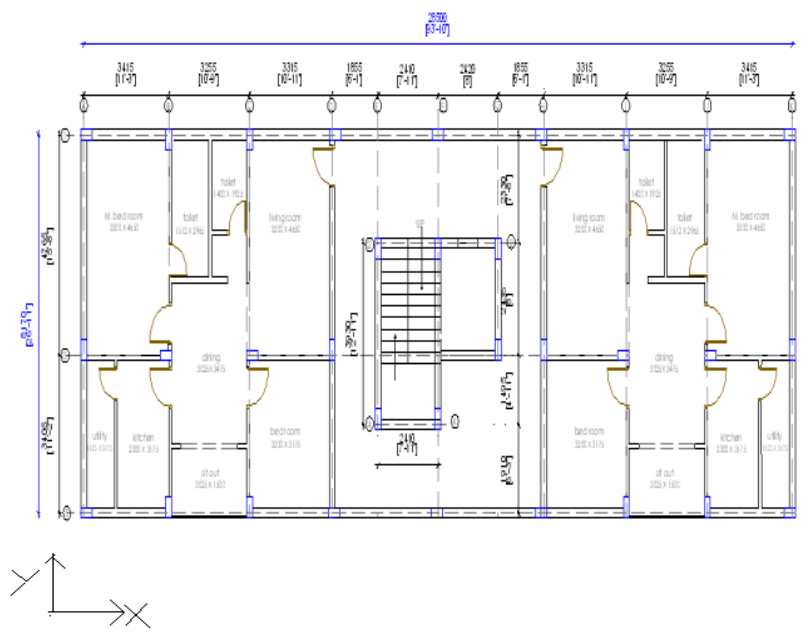

Fig - 1: Building Plan
The E-TABS software is used to develop 3D model and to carry out the analysis. Dynamic analysis of the building models is performed on ETABS. The lateral loads generated by ETABS correspond to the seismic zone $\mathrm{V}$ and the $5 \%$ damped response spectrum given in IS: 1893-2002.

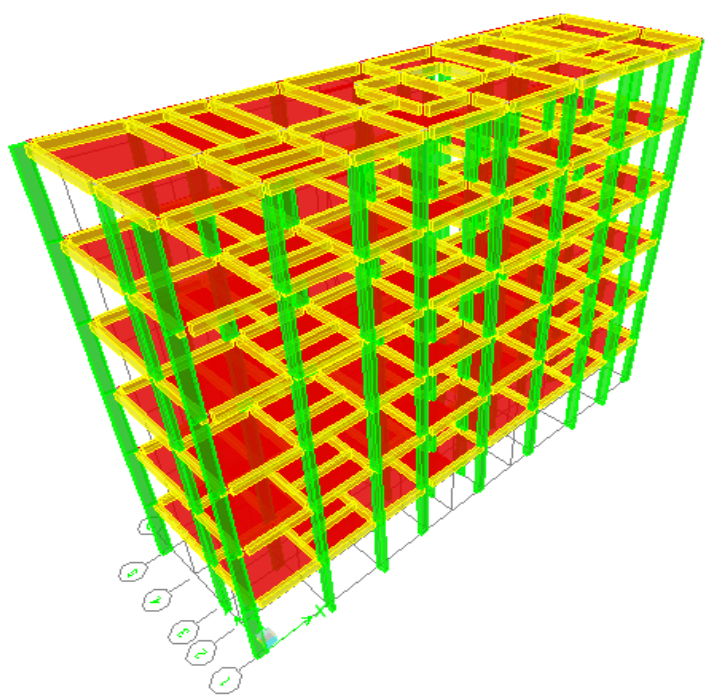

Fig -2: Bare Model

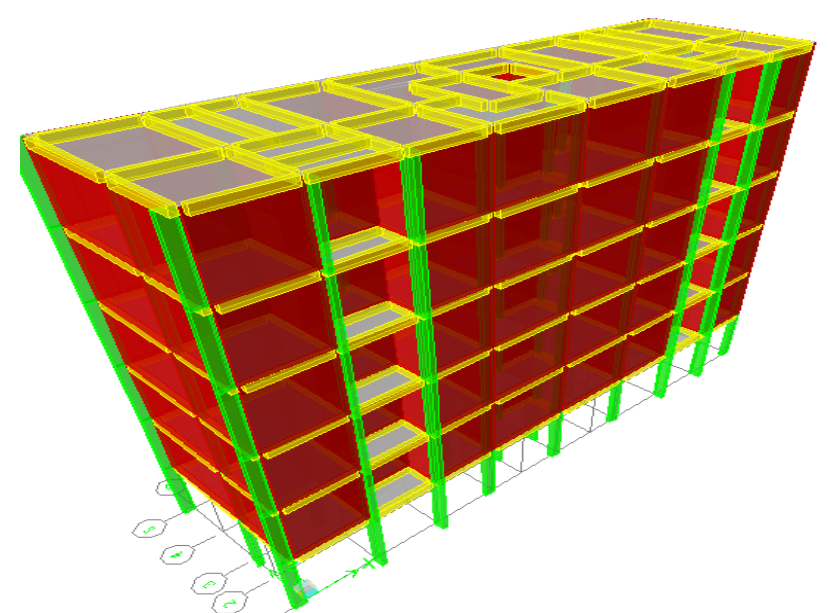

Fig -3: Open Bottom Storey

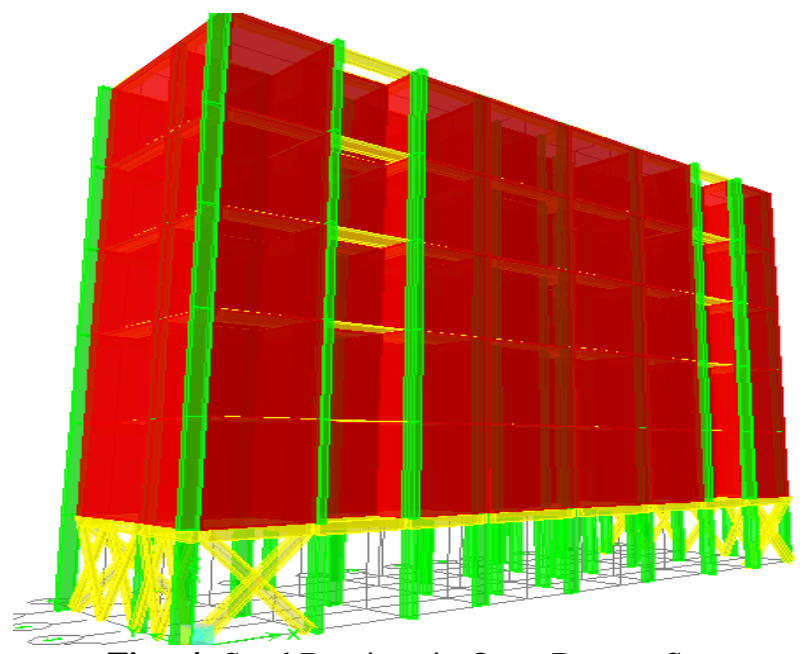

Fig - 4: Steel Bracings in Open Bottom Storey 


\subsection{Storey Drift}

It is the displacement of one level relative of the other level above or below. The storey drift in any storey shall not exceed 0.004 times the height of storey height

Height of Storey

$$
=4000 \mathrm{~mm}
$$$$
0.004(\mathrm{~h})=\quad 0.004(4000) \quad=16 \mathrm{~mm}
$$

Hence after analyzing the Building the results obtained for five models in both longitudinal and transverse direction and there comparisons are presented in tabular form.

Table - 2: Storey Drift of Building in Longitudinal direction

\begin{tabular}{|l|l|c|c|}
\hline $\begin{array}{l}\text { Bare } \\
\text { Model }\end{array}$ & $\begin{array}{l}\text { Open Bottom } \\
\text { Storey }\end{array}$ & $\begin{array}{l}\text { Steel Bracings } \\
\text { in Bottom } \\
\text { Storey }\end{array}$ & Storey no. \\
\hline 0.0009 & 0.000045 & 0.00008 & $\mathbf{6}$ \\
\hline 0.0017 & 0.000053 & 0.000094 & $\mathbf{5}$ \\
\hline 0.0022 & 0.000063 & 0.000113 & $\mathbf{4}$ \\
\hline 0.0025 & 0.000073 & 0.00015 & $\mathbf{3}$ \\
\hline 0.0028 & 0.000113 & 0.000272 & $\mathbf{2}$ \\
\hline 0.0022 & 0.004857 & 0.002009 & $\mathbf{1}$ \\
\hline
\end{tabular}

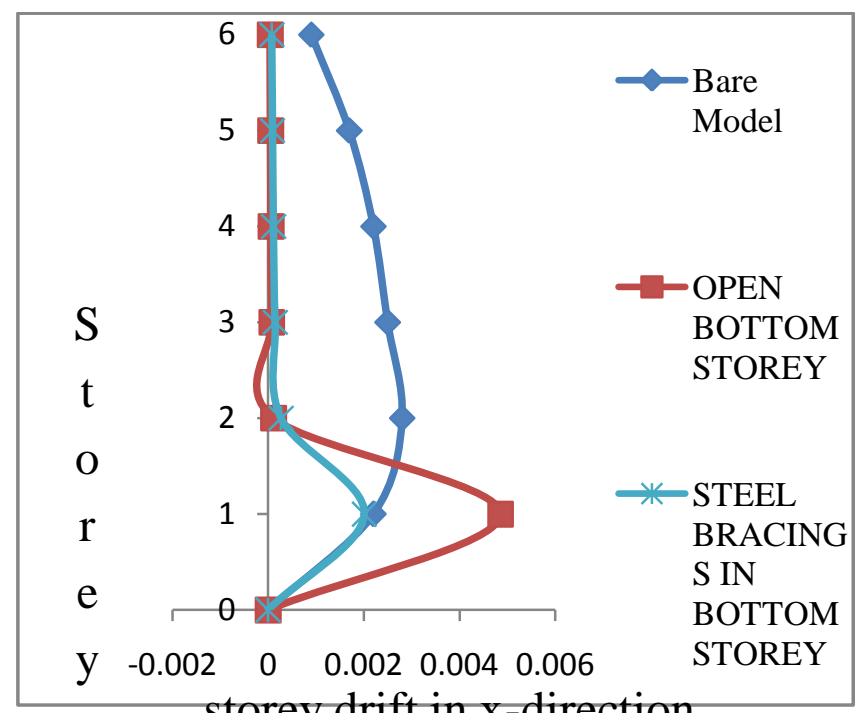

Fig - 5: Storey Drift of Building in Longitudinal direction

Table - 3: Storey Drift of Building in Transverse direction

\begin{tabular}{|c|c|c|c|}
\hline $\begin{array}{l}\text { Bare } \\
\text { Model } \\
\end{array}$ & \begin{tabular}{|l|} 
Open Bottom \\
Storey
\end{tabular} & \begin{tabular}{|lr} 
Steel & Bracings \\
in & Bottom \\
Storey & \\
\end{tabular} & Storey no. \\
\hline 0.0011 & 0.000279 & 0.000475 & 6 \\
\hline 0.0019 & 0.000287 & 0.000492 & 5 \\
\hline 0.0024 & 0.000293 & 0.000504 & 4 \\
\hline
\end{tabular}

\begin{tabular}{|l|l|l|l|}
\hline 0.0027 & 0.000296 & 0.00051 & $\mathbf{3}$ \\
\hline 0.0029 & 0.000305 & 0.000514 & $\mathbf{2}$ \\
\hline 0.0021 & 0.004272 & 0.001891 & $\mathbf{1}$ \\
\hline
\end{tabular}

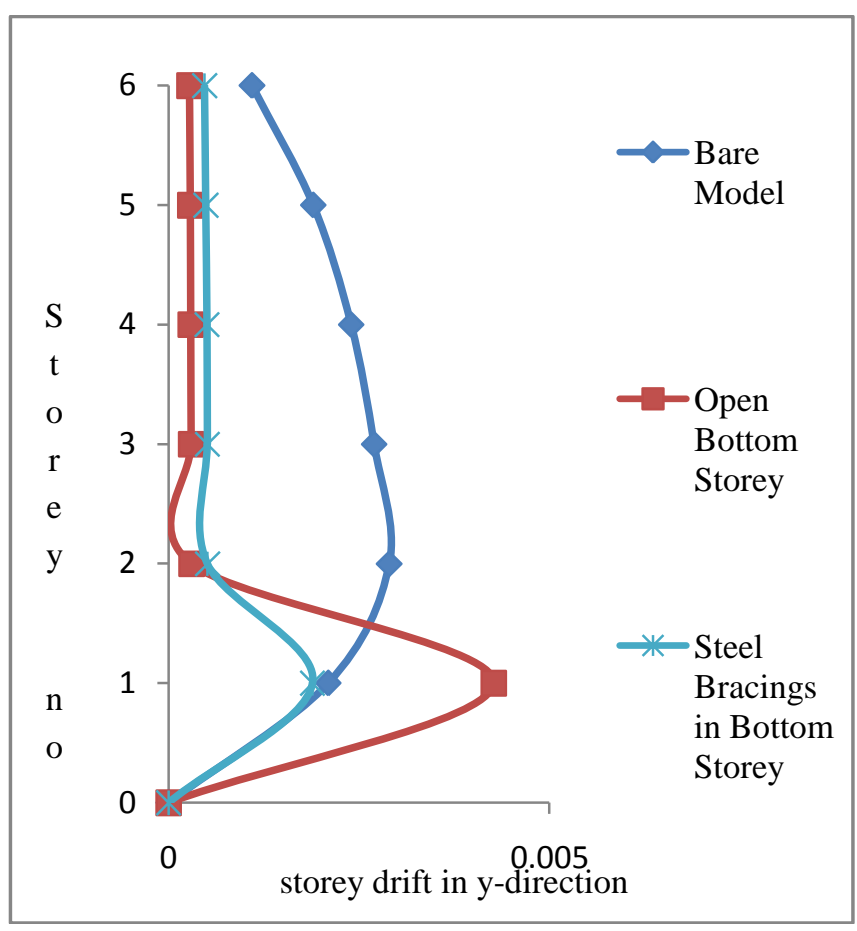

Fig - 6: Storey Drift of Building in Transverse direction

\subsection{Lateral Displacements}

It is displacement caused by the Lateral Force on the each storey level of structure. Lateral displacement will be more on top storey. Hence after analyzing the Building the results obtained for five models in both longitudinal and transverse direction and there comparison is presented in tabular form.

Table - 4: Lateral Displacements of Building in Longitudinal direction

\begin{tabular}{|c|c|c|c|}
\hline $\begin{array}{l}\text { Bare } \\
\text { Model } \\
(\mathbf{m m})\end{array}$ & $\begin{array}{l}\text { Open } \\
\text { Bottom } \\
\text { Storey (mm) }\end{array}$ & $\begin{array}{l}\text { Steel Bracings in } \\
\text { Bottom } \\
\text { Storey(mm) }\end{array}$ & Storey no. \\
\hline 46.29 & 20.58 & 9.98 & $\mathbf{6}$ \\
\hline 43.29 & 20.4 & 9.67 & $\mathbf{5}$ \\
\hline 37.7 & 20.21 & 9.32 & $\mathbf{4}$ \\
\hline 33.9 & 19.97 & 8.91 & $\mathbf{3}$ \\
\hline 20.15 & 19.75 & 8.43 & $\mathbf{2}$ \\
\hline 8.81 & 19.35 & 7.56 & $\mathbf{1}$ \\
\hline
\end{tabular}




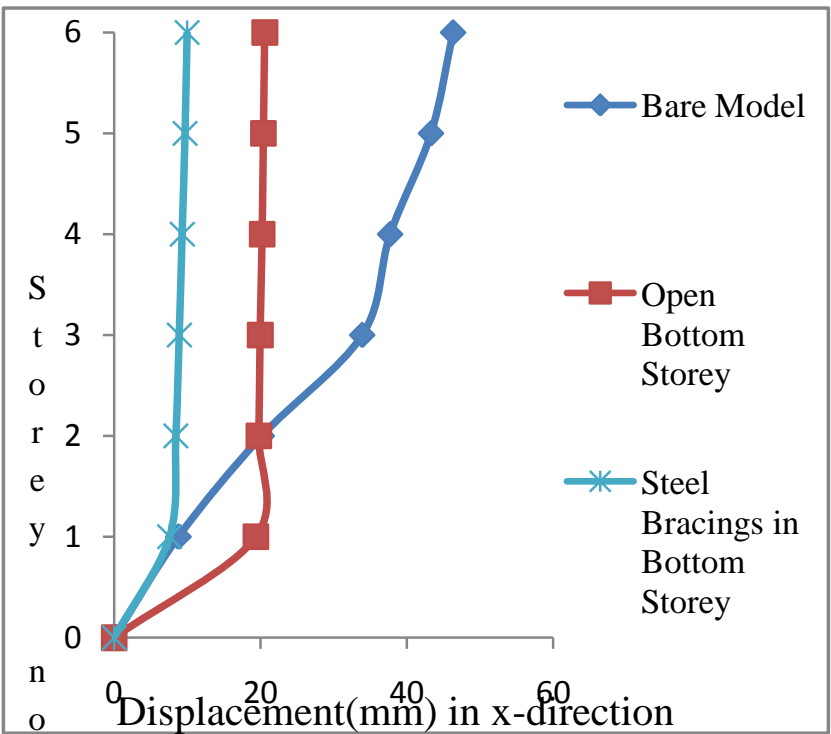

Fig - 7: Lateral Displacements of Building in Longitudinal direction

Table - 5: Lateral Displacements of Building in Transverse direction

\begin{tabular}{|c|c|c|c|}
\hline $\begin{array}{c}\text { Bare } \\
\text { Model(mm) }\end{array}$ & $\begin{array}{l}\text { Open Bottom } \\
\text { Storey(mm) }\end{array}$ & $\begin{array}{l}\text { Steel Bracings } \\
\text { in } \begin{array}{r}\text { Bottom } \\
\text { Storey(mm) }\end{array}\end{array}$ & $\begin{array}{l}\text { Storey } \\
\text { no. }\end{array}$ \\
\hline 50.19 & 22.54 & 16 & $\mathbf{6}$ \\
\hline 46.25 & 21.44 & 14.11 & $\mathbf{5}$ \\
\hline 39.7 & 20.31 & 12.15 & $\mathbf{4}$ \\
\hline 31 & 19.18 & 10.14 & $\mathbf{3}$ \\
\hline 20.38 & 18.09 & 8.11 & $\mathbf{2}$ \\
\hline 8.47 & 17.08 & 6.09 & $\mathbf{1}$ \\
\hline
\end{tabular}

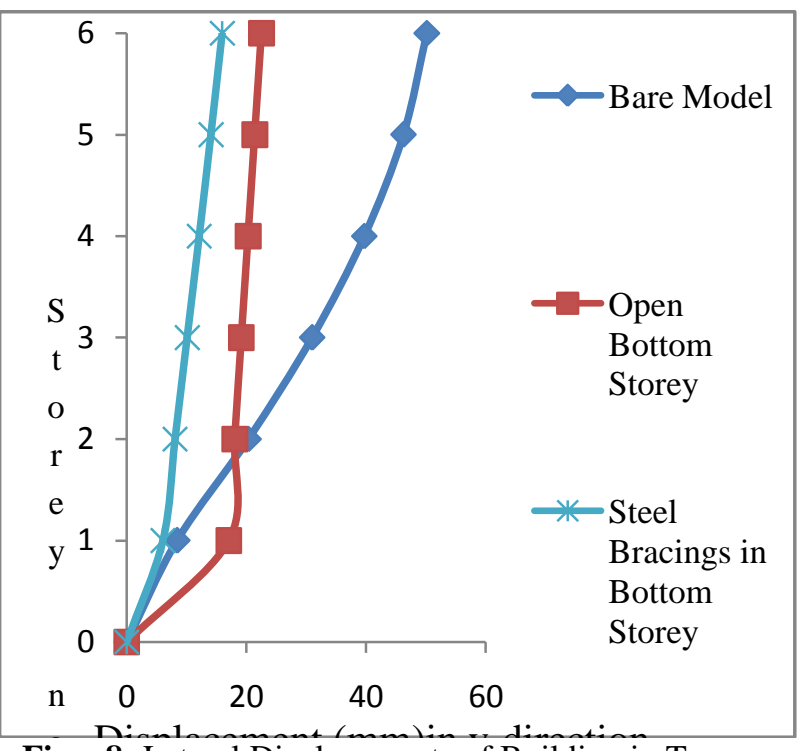

Fig - 8: Lateral Displacements of Building in Transverse direction

\subsection{Lateral Force}

It is the horizontal seismic force acting on perpendicular to the axis of structure. Hence after analyzing the Building the results obtained for five models in both longitudinal and transverse direction and there comparisons are presented in tabular form.

Table - 6: Comparisons of Lateral Forces $(\mathrm{kN})$ in Longitudinal direction for five models

\begin{tabular}{|c|c|c|c|}
\hline $\begin{array}{l}\text { Bare } \\
\text { Model(kN) }\end{array}$ & $\begin{array}{l}\text { Open } \\
\text { Bottom } \\
\text { Storey(kN) }\end{array}$ & $\begin{array}{l}\text { Steel } \\
\text { Bracings in } \\
\text { Bottom } \\
\text { Storey(kN) }\end{array}$ & $\begin{array}{l}\text { Storey } \\
\text { No }\end{array}$ \\
\hline 283 & 457 & 459 & $\mathbf{6}$ \\
\hline 296 & 689 & 694 & $\mathbf{5}$ \\
\hline 170 & 681 & 687 & $\mathbf{4}$ \\
\hline 107 & 672 & 679 & $\mathbf{3}$ \\
\hline 141 & 663 & 672 & $\mathbf{2}$ \\
\hline 94 & 459 & 468 & $\mathbf{1}$ \\
\hline
\end{tabular}

Table -7: Comparisons of Lateral Forces $(\mathrm{kN})$ in Transverse direction for five models

\begin{tabular}{|c|c|c|c|}
\hline $\begin{array}{l}\text { Bare } \\
\text { Model(kN) }\end{array}$ & $\begin{array}{l}\text { Open } \\
\text { Bottom } \\
\text { Storey(kN) }\end{array}$ & $\begin{array}{l}\text { Steel } \\
\text { Bracings in } \\
\text { Bottom } \\
\text { Storey(kN) }\end{array}$ & $\begin{array}{l}\text { Storey } \\
\text { No }\end{array}$ \\
\hline 286 & 526 & 526 & $\mathbf{6}$ \\
\hline 281 & 749 & 750 & $\mathbf{5}$ \\
\hline 141 & 700 & 703 & $\mathbf{4}$ \\
\hline 105 & 656 & 661 & $\mathbf{3}$ \\
\hline 141 & 618 & 625 & $\mathbf{2}$ \\
\hline 90 & 411 & 419 & $\mathbf{1}$ \\
\hline
\end{tabular}

\subsection{Design Seismic Base Shear ( Vb):}

It is the total design lateral force at the base of a structure. Hence after analyzing the Building the results obtained for five models in both longitudinal and transverse direction and there comparisons are presented in tabular form 
Table - 8: Comparisons of Base Shear $(\mathrm{kN})$

\begin{tabular}{|c|c|c|c|}
\hline Direction & $\begin{array}{c}\text { With No } \\
\text { Infill } \\
(\mathbf{k N})\end{array}$ & $\begin{array}{c}\text { Open } \\
\text { Ground } \\
\text { Storey } \\
\mathbf{( k N )}\end{array}$ & $\begin{array}{c}\text { Steel } \\
\text { Bracings In } \\
\text { Bottom } \\
\text { Storey (kN) }\end{array}$ \\
\hline Longitudinal & 1091 & 3621 & 3659 \\
\hline Transverse & 1044 & 3660 & 3684 \\
\hline
\end{tabular}

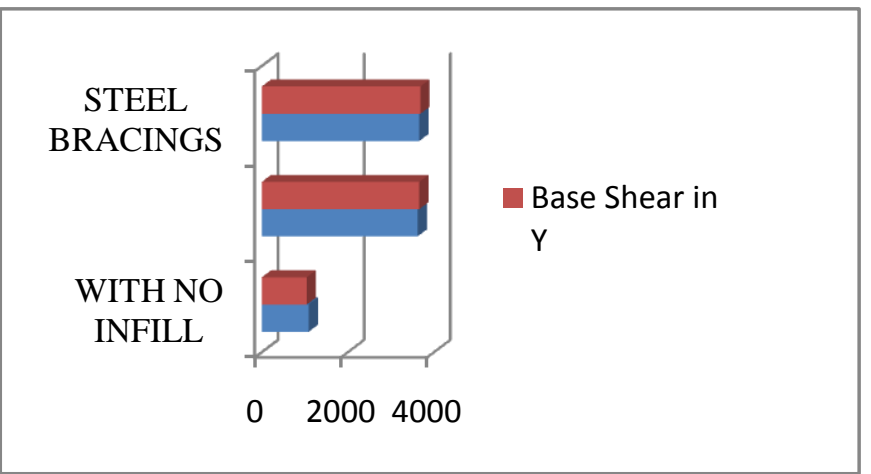

Figure - 9: Comparisons of Base Shear $(\mathrm{kN})$

\subsection{Torsion:}

Table - 9: Comparisons of Torsion $(\mathrm{kN}-\mathrm{m})$

\begin{tabular}{|c|c|c|c|}
\hline Storey No. & $\begin{array}{c}\text { With No } \\
\text { Infill } \\
\mathbf{( k N m )}\end{array}$ & $\begin{array}{c}\text { Open } \\
\text { Ground } \\
\text { Storey } \\
\mathbf{( k N m )}\end{array}$ & $\begin{array}{c}\text { Steel Bracings } \\
\text { In Bottom } \\
\text { Storey } \\
\text { (kNm) }\end{array}$ \\
\hline $\mathbf{6}$ & 1143 & 2010 & 1868 \\
\hline $\mathbf{5}$ & 1206 & 3103 & 2839 \\
\hline $\mathbf{4}$ & 673 & 3056 & 2818 \\
\hline $\mathbf{3}$ & 486 & 3023 & 2793 \\
\hline $\mathbf{2}$ & 572 & 2986 & 2764 \\
\hline $\mathbf{1}$ & 375 & 2051 & 1913 \\
\hline & 4455 & 16229 & 14995 \\
\hline & & & \\
\hline
\end{tabular}

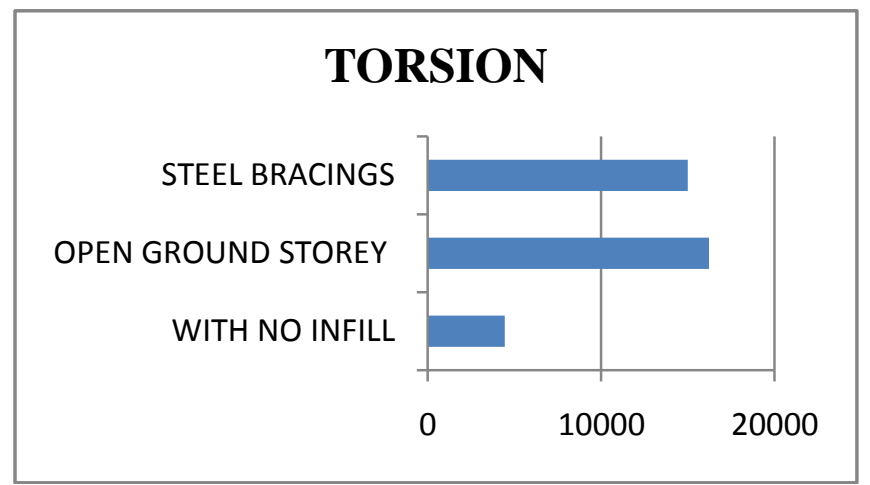

Fig - 10: Comparisons of Torsion (kN-m)

\subsection{Fundamental Natural Period $\left(T_{\mathfrak{i}}\right)$}

It is the first (longest) modal time period of vibration Hence after analyzing the Building the results obtained for five models in both longitudinal and transverse direction and there comparisons' are presented in tabular form
Table - 10: Comparisons of Time Period (sec)

\begin{tabular}{|c|c|c|c|}
\hline & $\begin{array}{l}\text { With } \\
\text { No } \\
\text { Infill } \\
\text { Direction }\end{array}$ & $\begin{array}{l}\text { Open } \\
\text { Ground } \\
\text { Storey } \\
\text { (Sec })\end{array}$ & $\begin{array}{l}\text { Steel } \\
\text { Bracings In } \\
\text { Bottom } \\
\text { Storey } \\
\text { (Sec })\end{array}$ \\
\hline Longitudinal & 1.767 & 0.9727 & 0.492 \\
\hline Transverse & 1.848 & 0.9606 & 0.586 \\
\hline
\end{tabular}

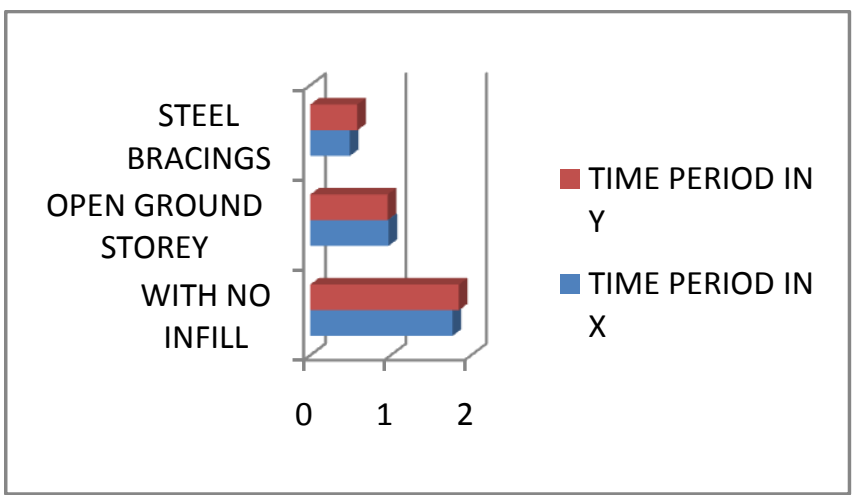

Fig - 11: Comparisons of Time Period (sec)

\subsection{Stiffness}

It is the rigidity of an object - the extent to which it resists deformation in response to the applied force.

$$
\mathrm{K}=\frac{P}{\Delta}
$$

Hence after analyzing the Building the results obtained in both longitudinal and transverse direction and there comparisons are presented in tabular form.

\subsection{Soft Storey:}

It is one in which the lateral stiffness is less than 70 percent of that in the storey above.

Table - 11: Calculation of Stiffness $(\mathrm{kN} / \mathrm{m})$ for open Bottom Storey model in Longitudinal Direction

\begin{tabular}{|c|c|c|c|c|}
\hline \multicolumn{5}{|c|}{ Open Bottom Storey } \\
\hline $\begin{array}{c}\text { Storey } \\
\text { No. }\end{array}$ & Load(kN) & Displacements(mm) & $\begin{array}{c}\text { Stiffness } \\
(\mathbf{k N / m})\end{array}$ & Ratio \\
\hline $\begin{array}{c}\text { (top } \\
\text { storey)6 }\end{array}$ & 457 & 20.58 & 22206 & \\
\hline 5 & 689 & 20.4 & 33775 & \\
\hline 4 & 681 & 20.21 & 33696 & \\
\hline 3 & 672 & 19.97 & 33650 & \\
\hline 2 & 670 & 19.75 & 33924 & \\
\hline 1 & 452 & 19.45 & 23239 & 68 \\
\hline
\end{tabular}


Table - 12: Calculation of Stiffness $(\mathrm{kN} / \mathrm{m})$ for Steel Bracings model in Longitudinal Direction

\begin{tabular}{|c|c|c|c|c|}
\hline \multicolumn{5}{|c|}{ Steel Bracings In Bottom Storey } \\
\hline $\begin{array}{c}\text { Storey } \\
\text { No. }\end{array}$ & Load(kN) & Displacements(mm) & $\begin{array}{c}\text { Stiffness } \\
(\mathbf{k N / m})\end{array}$ & Ratio \\
\hline $\begin{array}{c}\text { (top } \\
\text { storey)6 }\end{array}$ & 459 & 9.98 & 45992 & \\
\hline 5 & 694 & 9.67 & 71768 & \\
\hline 4 & 687 & 9.32 & 73712 & \\
\hline 3 & 679 & 8.91 & 76206 & \\
\hline 2 & 672 & 8.43 & 79715 & \\
\hline 1 & 468 & 7.56 & 61904 & $\mathbf{7 7}$ \\
\hline
\end{tabular}

Here lateral stiffness is more than 70 percent of that in the storey above. Hence it is safe when steel braced system is provided in open bottom storey.

Table - 13: Calculation of Stiffness for open Bottom Storey model in Transverse Direction

\begin{tabular}{|c|c|c|c|c|}
\hline \multicolumn{5}{|c|}{ Open Bottom Storey } \\
\hline $\begin{array}{c}\text { Storey } \\
\text { No. }\end{array}$ & $\operatorname{Load}(\mathbf{k N})$ & Displacements $(\mathrm{mm})$ & $\begin{array}{c}\text { Stiffness } \\
(\mathrm{kN} / \mathrm{m})\end{array}$ & Ratio \\
\hline $\begin{array}{c}\text { (top } \\
\text { storey)6 } \\
\end{array}$ & 526 & 22.54 & 23336 & \\
\hline 5 & 749 & 21.44 & 34935 & \\
\hline 4 & 700 & 20.31 & 34466 & \\
\hline 3 & 656 & 19.18 & 34202 & \\
\hline 2 & 638 & 18.09 & 35268 & \\
\hline 1 & 411 & 17.08 & 24063 & 68 \\
\hline
\end{tabular}

Table - 14: Calculation of Stiffness for steel bracing model in Transverse Direction

\begin{tabular}{|c|c|c|c|c|}
\hline \multicolumn{5}{|c|}{ Steel Bracings In Bottom Storey } \\
\hline $\begin{array}{c}\text { Storey } \\
\text { No. }\end{array}$ & Load(kN) & Displacements(mm) & $\begin{array}{c}\text { Stiffness } \\
(\mathbf{k N / m})\end{array}$ & Ratio \\
\hline $\begin{array}{c}\text { (top } \\
\text { storey)6 }\end{array}$ & 526 & 16 & 32875 & \\
\hline 5 & 750 & 14.11 & 53153 & \\
\hline 4 & 703 & 12.15 & 57860 & \\
\hline 3 & 661 & 10.14 & 65187 & \\
\hline 2 & 625 & 8.11 & 77065 & \\
\hline 1 & 419 & 6.09 & 68801 & $\mathbf{8 9}$ \\
\hline
\end{tabular}

Here lateral stiffness is more than 70 percent of that in the storey above. Hence it is safe when steel braced system is provided in open bottom storey.

\section{OBSERVATIONS AND CONCLUSIONS}

1. Storey drift of steel braced system at bottom storey is within the limit as clause no 7.11.1 of IS-1893 (Part-1):2002.

2. Storey Stiffness of steel braced model at bottom storey is within the limit as clause no 4.20 of IS1893 (Part-1):2002.

3. Deflection in case of bare frame is very large, when compared to other cases. The presence of steel bracing system can affect the seismic behavior of frame structure to large extent, and the steel bracing system increases stiffness of the structure.

4. It is found that the steel bracing system at open bottom storey significantly contributes to the structural stiffness and reduces the maximum inter story drift, lateral displacement of R.C.C building.

5. It is found that the $X$ type of steel bracing system at bottom storey has less torsion effect.

RC frame buildings with open bottom storey are known to perform poorly during in strong earthquake shaking. Thus, it is clear that such buildings will exhibit poor performance during a strong shaking. This hazardous feature of Indian $\mathrm{RC}$ frame buildings needs to be recognized immediately and necessary measures taken to improve the performance of the buildings.

\section{REFERENCES}

[1] Haroon Rasheed Tamboli - Seismic Analysis of RC Frame Structure with and without Masonry Infill Walls. International Journal of Scientific \& Engineering Research(IJSER) June-2012

[2] Kevadkar and Kodag-Lateral Load Analysis of R.C.C. Building . International Journal of Modern Engineering Research (IJMER) www.ijmer.com Vol.3, Issue.3, May-June. 2013

[3] Rahul p.Rathiand Dr.P.SPatgade- Study of Masonary Infilled R.C. Frame With \& Without Opening. International Journal of Scientific \& Engineering Research Volume 3, Issue 6, June2012.

[4] L. Teresa Guevara-Perez 5 - "Soft Story" and "Weak Story" in Earthquake Resistant Design: 15 WCEE LISBOE 2012

[5] Dr. Sudhir K Jain - Explanatory Examples on Indian Seismic Code IS 1893 (Part I) Department of Civil Engineering Indian Institute of Technology Kanpur.

[6] Dr. H. J. Shah - Design Example of a Six Storey Building Department of Applied Mechanics M. S. University of Baroda .Vadodara.

[7] Agarwal P. and M Shrikhande (2007), "Earthquake Resistant Design of Structures", Prentice Hall of India Pvt. Ltd., 2007, New Delhi. 
[8] IITK-BMTPC (2004), "Earthquake Tip \#21 - Why are Open-Ground Storey Buildings Vulnerable in Earthquakes?", 2005, www.nicee.org, IIT-Kanpur.

[9] IS 1893 (Part 1)- 2002, “Criteria For Earthquake Resistant Design Of Structures"- Part 1General Provisions And Buildings", 5th Revision, 2002, BUREAU OF INDIAN STANDARDS, New Delhi, INDIA

\section{BIOGRAPHIES}

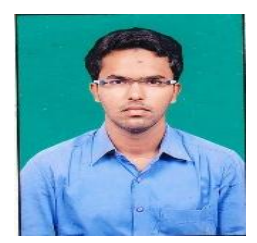

Shaik. Zubair Ahmed Post Graduate Student, Structural Engineering Department, Civil Engineering, G.PullaReddy Engineering College, Kurnool, Andhra Pradesh, India

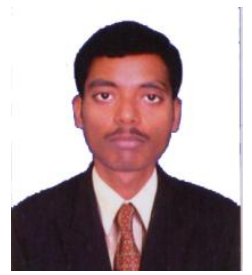

K.V.Ramana obtained his Master's degree from university college of Engineering JNTUK, Kakinada in 2011. He worked as a Lecturer in University college of Engineering, Kakinada for 2 years. Later he joined as an ASSISTANT PROFESSOR in G. Pulla Reddy Engineering College, Kurnool and continues now. He Participated and Published papers in both National and International Conferences. He has interest on Rehabilitation and Retrofitting of structures and structural dynamics. He applied Research Projects under SEED division in DST and UGC also.

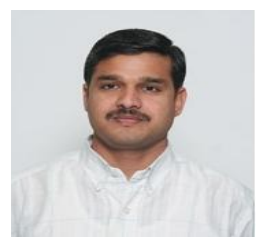

Dr. Ramancharla has done his Ph.D. (Earthquake Engg.), Univ. of Tokyo, Japan. $\mathrm{He}$ is Co-coordinator for Computer Aided Structural Engineering (CASE) and Head of Earthquake Engineering Research Centre (EERC). He has published around 50 papers in various journals, national and international conferences. 